\title{
Effectiveness of Ford's belt reminder system in increasing seat belt use
}

\section{A F Williams, J K Wells, C M Farmer}

Injury Prevention 2002;8:293-296

See end of article for authors' affiliations .....................

Correspondence and reprint requests to: Dr Allan F Williams, Insurance Institute for Highway Safety, 1005 North Glebe Road, Arlington, Virginia 22201-4751, USA; awilliams@iihs.org

\begin{abstract}
Objectives: The study investigated the effectiveness in increasing seat belt use of Ford's belt reminder system, a supplementary system that provides intermittent flashing lights and chimes for five minutes if drivers are not belted.

Methods: Seat belt use of drivers in relatively new cars with and without the reminder system was unobtrusively observed as vehicles were brought to dealerships for service.

Results: Overall use rates were estimated at $71 \%$ for drivers in vehicles without the reminder system and $76 \%$ for drivers in vehicles with belt reminders $(p<0.01)$.

Conclusions: Seat belt use is relatively low in the United States. The present study showed that vehicle based reminder systems can be at least modestly effective in increasing belt use, which may encourage further development of such systems.
\end{abstract}

$\mathrm{S}$ eat belts, if used, protect against serious and fatal crash injuries, but getting motorists to use belts has been a problem. Some people do so voluntarily, but in the early days of seat belts, observations of drivers in the United States indicated that less than $20 \%$ were using available belts. ${ }^{1}$ Low seat belt use was common in all motorized societies in the late 1960s and early 1970s. Educational and advertising campaigns were used in the United States and elsewhere to try to increase use, but by themselves they had little success. ${ }^{2-7}$

In the early 1970s, the United States tried to increase belt use using technological approaches. In cars manufactured in 1972 and 1973, a buzzer-light was activated for at least one minute if the front outboard belts were not fastened. ${ }^{8}$ Starting in August 1973, new cars were required to have interlocks that would not allow a car to be started if belts were not used by front seat occupants. ${ }^{9}$ Observational studies indicated that although the buzzer-light did not increase belt use, the starter interlock did. Belt use in cars with interlocks was 59\% compared with $28 \%$ in prior model year cars with buzzerlights. ${ }^{10}$ However, because of complaints from the public, the interlock requirement was rescinded. Congress also prohibited the National Highway Traffic Safety Administration (NHTSA) from issuing any future safety standard that would require either a seat belt interlock or a continuous buzzer of more than eight seconds to indicate that belts are not in use.

Countries around the world turned to belt laws as a way of increasing use, beginning with Victoria, Australia, in 1970. Many of the laws have been very effective, achieving belt use rates in excess of $90 \%$, but the success rate has been lower in some countries, including the United States. The more limited success with belt laws in the United States has led to renewed interest in vehicle based systems to increase belt use. Ironically, even greater interest in this approach has been found in Sweden. Sweden has a belt use rate of about $90 \%$ but, because belt use typically is lower among high risk drivers, belt use in serious crashes is substantially lower than $90 \% .{ }^{11}$ The reminder system being experimented with in Sweden involves sound and pulsating lights that increase in intensity with distance or speed. The intention is to develop a reminder that is both effective and not overly annoying. Focus groups in Sweden and Australia indicate these prototype systems would be acceptable to people who describe themselves as part time belt users. ${ }^{12}{ }^{13}$

Subsequent to the experience with the buzzer-light and interlock in the early 1970s, Federal Motor Vehicle Safety
Standard 208 since 1975 has required new cars to display a warning light and a 4-8 second audible signal if the driver does not fasten the seat belt after starting the vehicle. ${ }^{14}$ Most manufacturers use an intermittent chime that continues for a few seconds. This system is not commonly considered to be an effective belt use inducer, although its contribution to belt use has not been formally evaluated.

Manufacturers can do more than meet these minimum criteria. For example, late model Toyotas have a continuous flashing light to alert front seat occupants to buckle their seat belts. Beginning in the 2000 model year, Ford began equipping new vehicles with the Belt-Minder system, a supplementary system involving both light and sound that is activated after the initial belt reminder stops chiming. Belt-Minder, a registered trademark of Ford Motor Company, is referred to in this paper as the belt reminder system. Depending on the electronics of the vehicle, the system is activated either when the engine is started or when the engine is started and the vehicle is going about $3 \mathrm{mph}$ or more. If the driver remains unbuckled, the system sounds a chime while flashing a "buckle safety belt" warning light on the instrument panel. The system flashes and chimes for six seconds, pauses for 30 seconds, and then repeats for up to five minutes. If the driver fastens the seat belt, the system is deactivated.

The purpose of the present study was to determine if Ford's belt reminder system increases driver seat belt use among new vehicle owners.

\section{METHODS}

The belt reminder system was introduced in some 2000 model year Ford passenger cars and utility vehicles, in most 2001 Fords, and in all 2002 Fords. An observational survey was conducted to compare driver belt use in 2000-02 models with belt reminders with belt use in 1998-2001 models without reminders.

With the cooperation of Ford, observations of driver belt use were made unobtrusively at 12 Ford owned dealerships in August and September 2001 when vehicles were brought in

Abbreviations: NHTSA, National Highway Traffic Safety Administration; VIN, vehicle identification number 
Table 1 Observed vehicles by model year

\begin{tabular}{|c|c|c|c|c|c|c|}
\hline & \multicolumn{5}{|c|}{ Model year } & \multirow[b]{2}{*}{ Total } \\
\hline & 1998 & 1999 & 2000 & 2001 & 2002 & \\
\hline \multicolumn{7}{|l|}{ Without belt reminders } \\
\hline Car/minivan & 205 & 314 & 121 & 0 & & 640 \\
\hline Pickup & 41 & 132 & 212 & 0 & & 385 \\
\hline Utility vehicle & 148 & 150 & 158 & 15 & & 471 \\
\hline Large passenger/cargo van & 9 & 6 & 10 & 0 & & 25 \\
\hline Total & 403 & 602 & 501 & 15 & & 1521 \\
\hline \multicolumn{7}{|l|}{ With belt reminders } \\
\hline Car/minivan & & & 280 & 183 & 5 & 468 \\
\hline Pickup & & & 0 & 185 & 4 & 189 \\
\hline Utility vehicle & & & 15 & 110 & 22 & 147 \\
\hline Large passenger/cargo van & & & 4 & 5 & 0 & 9 \\
\hline Total & & & 299 & 483 & 31 & 813 \\
\hline
\end{tabular}

for service. Six of the dealerships were in Tulsa, Oklahoma, and six were in Oklahoma City. Observations were made of driver shoulder belt use, gender, and license number. It was possible to observe all vehicles being brought in for service when the survey was conducted. While the cars were being serviced, repair orders were examined to obtain the vehicle identification number (VIN) so as to identify model year and whether the vehicle had the belt reminder system. To identify 2000 model year vehicles with and without belt reminders, VINs were supplemented with information provided by Ford as to when manufacturing plants started installing the system.

Seat belt use rates in vehicles with and without the belt reminder system were computed separately for each combination of vehicle type (car/minivan, pickup, utility vehicle) and driver gender. There were five drivers for whom gender could not be determined. Also, there were only 34 large passenger/ cargo vans observed ( 25 without belt reminders and nine with them), too few to make any determination of use rate differences. Statistical analyses were restricted to the remaining 2295 observations ( 1495 without and 800 with belt reminders).

Overall use rates for vehicles with and without the belt reminder system were computed as weighted averages of the vehicle-type-by-gender use rates. The weights were equal to the proportion of the 1495 observed vehicles without belt reminders in each of the six vehicle-type-by-gender categories. Thus the overall use rate for non-belt reminder vehicles is simply the use rate for the combined non-belt reminder sample. However, the overall use rate for belt reminder vehicles is what would have been expected if the vehicle-type-by-gender distribution of observed belt reminder vehicles had been the

Table 2 Observed driver seat belt use in passenger vehicles with and without belt reminders

\begin{tabular}{|c|c|c|c|c|}
\hline \multirow{2}{*}{$\begin{array}{l}\text { Vehicle } \\
\text { type/driver } \\
\text { gender }\end{array}$} & \multicolumn{2}{|c|}{ Seat belt use rates $(\%)$} & \multirow{2}{*}{ Difference } & \multirow{2}{*}{$\begin{array}{l}95 \% \\
\text { confidence } \\
\text { intervals }\end{array}$} \\
\hline & $\begin{array}{l}\text { No } \\
\text { reminder }\end{array}$ & Reminder & & \\
\hline \multicolumn{5}{|c|}{ Car/minivan } \\
\hline Male & 74 & 77 & 3 & -3.5 to 10.4 \\
\hline Female & 81 & 86 & 5 & -1.9 to 11.0 \\
\hline \multicolumn{5}{|l|}{ Pickup } \\
\hline Male & 58 & 66 & 8 & -1.0 to 17.0 \\
\hline Female & 72 & 76 & 4 & -16.9 to 24.9 \\
\hline \multicolumn{5}{|c|}{ Utility vehicle } \\
\hline Male & 68 & 73 & 4 & -6.7 to 15.2 \\
\hline Female & 76 & 84 & 8 & -3.1 to 18.8 \\
\hline
\end{tabular}

same as that of the non-belt reminder vehicles (there were more pickups and utility vehicles in the non-belt reminder sample).

Statistical procedures involved approximating use rates by independent normal random variables, yielding standard tests and confidence intervals for differences in proportions.

\section{RESULTS}

Observed vehicles without the belt reminder system were approximately equally distributed across the 1998-2000 model years, as shown in table 1. Fifty nine percent of the belt reminder vehicles, however, were 2001 models. In particular, almost all of the pickups with reminders were 2001 models (the remaining four were 2002 models).

Table 2 lists driver belt use rates for non-reminder and reminder vehicles in each of the six vehicle-type-by-gender categories. In each case the use rate was higher for vehicles with reminders. Differences ranged from three percentage points for male drivers of cars and minivans to eight percentage points for both male drivers of pickups and female drivers of utility vehicles, but none of these was statistically significant.

In both Oklahoma City and Tulsa, cars and minivans made up a higher percentage of the belt reminder sample than the non-belt reminder sample. Also, car and minivan drivers were more likely to be male, and utility vehicle drivers were more likely to be female in the belt reminder sample than in the non-belt reminder sample. The non-belt reminder percentages of table 3 were the weights used to average the belt use rates of table 2. This served to equalize the vehicle type and driver gender distributions of the two samples.

Table 4 lists driver belt use rates for non-reminder and reminder vehicles combined across vehicle type categories,

\begin{tabular}{|c|c|c|}
\hline $\begin{array}{l}\text { Table } 3 \text { Percen } \\
\text { vehicles/drivers }\end{array}$ & $\begin{array}{l}\text { ge }{ }^{*} \text { of ob } \\
\text { ach type }\end{array}$ & erved \\
\hline $\begin{array}{l}\text { Vehicle type/driver } \\
\text { gender }\end{array}$ & $\begin{array}{l}\text { No } \\
\text { reminder }\end{array}$ & Reminder \\
\hline \multicolumn{3}{|l|}{ Car/minivan } \\
\hline Male & 22 & 32 \\
\hline Female & 21 & 26 \\
\hline \multicolumn{3}{|l|}{ Pickup } \\
\hline Male & 22 & 20 \\
\hline Female & 3 & 3 \\
\hline \multicolumn{3}{|l|}{ Utility vehicle } \\
\hline Male & 20 & 10 \\
\hline Female & 12 & 8 \\
\hline
\end{tabular}


Table 4 Estimated driver seat belt use in passenger vehicles with and without belt reminders

\begin{tabular}{|c|c|c|c|c|}
\hline & \multicolumn{2}{|c|}{ Seat belt use rates (\%) } & \multirow[b]{2}{*}{ Difference } & \multirow{2}{*}{$\begin{array}{l}95 \% \\
\text { confidence } \\
\text { intervals }\end{array}$} \\
\hline & $\begin{array}{l}\text { No } \\
\text { reminder }\end{array}$ & Reminder & & \\
\hline \multicolumn{5}{|l|}{ Vehicle type } \\
\hline Car/minivan & 77 & 81 & 4 & -0.8 to 8.8 \\
\hline Pickup & 60 & 67 & 7 & -0.9 to 15.8 \\
\hline Utility vehicle & 71 & 77 & 6 & -2.4 to 13.6 \\
\hline \multicolumn{5}{|l|}{ Driver gender } \\
\hline Male & 67 & 72 & 5 & 0.1 to 10.5 \\
\hline Female & 79 & 84 & 6 & 0.1 to 11.1 \\
\hline Overall & 71 & 76 & 5 & 1.5 to 9.3 \\
\hline
\end{tabular}

gender categories, and overall. For example, the overall use rate for drivers of reminder vehicles was estimated as $0.22 \times 77$ $+0.21 \times 86+0.22 \times 66+0.03 \times 76+0.20 \times 73+0.12 \times 84$ (from tables 2 and 3 ). Increases of four, seven, and six percentage points were estimated for drivers of cars/minivans, pickups, and utility vehicles, respectively, but none of these was statistically significant. Estimated increases for both male and female drivers, however, were statistically significant $(p<0.05)$. Overall use rates were estimated at $71 \%$ for drivers of vehicles without belt reminders and $76 \%$ for drivers of vehicles with reminders. This difference of five percentage points was statistically significant $(\mathrm{p}<0.01)$.

\section{DISCUSSION}

Front seat belt use in Oklahoma was $68 \%$ in 2000, somewhat below the national average, based on state surveys conducted for NHTSA. ${ }^{15}$ The presence of Ford's belt reminder system in new vehicles was associated with a driver belt use rate of $76 \%$ compared with $71 \%$ in vehicles without belt reminders, a gain of five percentage points. This is a modest but important gain, especially since it reaches the higher crash risk population that is the last to buckle up. ${ }^{16}$ Still, about $25 \%$ of the drivers at the Oklahoma dealerships were not using belts even with reminder systems. Drivers can ignore the reminder if they choose, and there are ways to circumvent it. It is possible, though not easy, to turn the system off indefinitely by following a series of steps described in the owner's manual. Buckling and then unbuckling the belt while the engine remains on also deactivates the system for that trip. It was not possible in this survey to determine which methods were used by those who were not belted.

It should be noted that although the reminder system increased use in this study when belt use was in the low 70s, the effect may not be the same in locations where the belt use is $80 \%-90 \%$ or greater.

Across the United States, seat belt use in pickups is particularly low. ${ }^{17}$ The largest increase in use with the belt reminder system at the Oklahoma dealerships was among male drivers of pickups. With the low number of pickups observed, this difference did not quite reach statistical significance, but there is the suggestion that this lower use group may be particularly affected by a belt reminder system.

For comparability, the survey was limited to drivers of newer vehicles. Observational surveys have indicated that drivers of new vehicles are somewhat more likely than drivers of older vehicles to use seat belts. ${ }^{18}$ However, within late model years, the differences are negligible, ${ }^{19}$ and there was no evidence that this affected the results within the narrow range of model years included here. For example, for pickups and utility vehicles without reminder systems, driver belt use rates essentially were the same over model years 1998-2000. Among drivers of cars without reminders, belt use was highest in 2000 models but higher in 1998 than in 1999 models.
With reminder systems, drivers of 2000 model year cars were somewhat more likely to use belts than drivers of 2001 models.

The interlock system installed in vehicles in the early 1970s was not acceptable to the public. However, the interlock was an aggressive method for inducing belt use, introduced in an era when few were using seat belts and belts were uncomfortable and in some cases difficult to use. The acceptability of belt use inducement systems is likely to be higher today, with belt systems that are more comfortable and easier to use, laws requiring belt use, much higher use rates, and many drivers who report using belts on some trips but not others. ${ }^{20}$ Ford did not conduct focus groups or surveys before introducing the belt reminder system, but Ford reports that subsequent customer research found high acceptance and virtually no complaints.

In 1998 NHTSA was petitioned to amend Federal Motor Vehicle Safety Standard 208 to require an effective seat belt inducement in new vehicles, other than an interlock or continuous buzzer of the type NHTSA is prohibited from requiring. ${ }^{21}$ Examples provided included a continuous visual warning on the instrument panel and disruption of electrical power to non-essential accessories such as the radio or air conditioning. NHTSA denied the petition on the grounds of uncertainty as to safety benefits and acceptability to the public, prominently citing the interlock experience. ${ }^{22}$

However, manufacturers are free to offer whatever belt use inducement system they choose and can go beyond what NHTSA has authority to require, as Ford has done. With advances in electronics, sophisticated technology is available to devise various types of inducement systems. The challenge lies in finding systems that are very effective yet have high consumer acceptance. The experimental Swedish system is more aggressive than Ford's system, but its acceptability to the American public is largely unknown. A national survey of United States licensed drivers in 2000 indicated that 53\% were in favor of a reminder system that gets louder or lights that get brighter as vehicle speed increases, ${ }^{23}$ a system similar to the Swedish one. In the same survey only $40 \%$ said they were in favor of a law requiring devices that would disable the radio unless seat belts were fastened. Fifty four percent said they were in favor of a law requiring carmakers to install devices making it impossible to drive a vehicle unless seat belts are fastened. Thus a majority supports an interlock type system, although among those opposed, three quarters are strongly opposed.

There are several reasons to expect further development of devices to induce belt use. The success of Ford's reminder system is an important step forward. In the 2002 appropriations bill for the United States Department of Transportation, there is language directing NHTSA to study the benefits and acceptability of technologies that may enhance seat belt usage in passenger vehicles, and any legislative or regulatory actions that may be necessary to enable the installation of such devices. ${ }^{24}$ The European New Car Assessment Program will now give credit to vehicles with seat belt reminders using both sound and light and meeting certain minimum criteria, a development that will encourage manufacturers to offer them.

Reminder systems are an attractive option for increasing belt use, along with strengthening use laws and enforcement. However, even with systems as successful or more successful than Ford's, the full benefits will be delayed. Initially, belt use inducement systems will only be in new cars, and drivers of new vehicles are more likely to use belts than drivers of older vehicles. Full benefits will occur only when more of the vehicle fleet has reminder systems, with more of these vehicles driven by the non-user population.

\section{ACKNOWLEDGEMENT}

This work was supported by the Insurance Institute for Highway Safety. 


\section{Key points}

- Many people in the United States do not use seat belts despite laws requiring use.

- The more limited success with belt laws in the United States has led to renewed interest in vehicle based systems to increase use.

- Ford has begun equipping new vehicles with a belt reminder system that flashes and chimes for six seconds, pauses for 30 seconds, and then repeats for up to five minutes.

- An observational study at 12 Ford owned dealerships in Oklahoma found that driver belt use in vehicles with belt reminders was $76 \%$, compared with $71 \%$ in vehicles without reminders, a statistically significant gain of five percentage points.

- Reminder systems are an attractive option for increasing belt use. The challenge lies in finding systems that are effective yet have high consumer acceptance.

\section{Authors' affiliations}

A F Williams, J K Wells, C M Farmer, Insurance Institute for Highway Safety, Arlington, Virginia

\section{REFERENCES}

1 National Highway Traffic Safety Administration. Presidential initiative for increasing seat belt use nationwide, recommendations from the Secretary of Transportation. Report No DOT HS 808576

Washington, DC: US Department of Transportation, 1997.

2 Robertson LS, Kelley AB, O'Neill B, et al. A controlled study of the effect of television messages on safety belt use. Am J Public Health 1974;64:1071-80

3 Robertson LS. Auto industry belt use campaign fails. Washington, DC: Insurance Institute for Highway Safety, 1977.

4 Mackay M. Seat belt use under voluntary and mandatory conditions and its effect on causalities. In: Evans L, Schwing RC, eds. Human behavior and traffic safety. New York, NY: Plenum Press, 1985: 259-78.

5 Fhaner G, Hane M. Seat belts: factors influencing their use; a literature survey. Accid Anal Prev 1973;5:27-43.

6 Kaye BK, Sapolsky BS, Montgomery DJ. Increasing seat belt use through PI\&E and enforcement: The Thumbs Up Campaign. J Saf Res 1995;26:235-45.

7 O'Neill B. Role of advocacy, education, and training in reducing motor vehicle crash losses. Proceedings of WHO meeting to develop a 5-year strategy for road traffic injury prevention. Geneva, Switzerland: World Health Organization, 2001: 32-40.
8 National Highway Traffic Safety Administration. Occupant crash protection in passenger cars, multipurpose passenger vehicles, trucks, and buses. Federal register. Washington, DC: Office of the Federal Register, National Archives and Records Administration, 1971;36:4605 (March'10).

9 National Highway Traffic Safety Administration. Occupant crash protection. Federal register. Washington, DC: Office of the Federal protection. Federal register. Washington, DC: Office of the Federal (February 24).

10 Robertson LS. Safety belt use in automobiles with starter-interlock and buzzer-light reminder systems. Am J Public Health 1975;65:1319-25.

11 Dahlstedt S. Non-users' motives for not wearing the seat belt. Linköping, Sweden: Swedish National Road and Transport Research Institute, 1999.

12 Larsson P. Seat belt reminder systems. Vägverket, Sweden: Swedish National Road Administration, Traffic Safety Department, 2000.

13 Harrison WA, Senserrick TM, Tingvall C. Development and trial of a method to investigate the acceptability of seat belt reminder systems. Report No 170. Victoria, Australia: Monash University Accident Research Centre, 2000.

14 National Highway Traffic Safety Administration. Occupant crash protection. Federal register. Washington, DC: Office of the Federal Register, National Archives and Records Administration, 1974;39:42693 (December 6)

15 National Center for Statistics and Analysis. 1998-2000 state shoulder belt use survey results. Research Note. Washington, DC. Available: http://www-nrd.nhtsa.dot.gov/pdf/nrd-30/NCSA/ Available: http://www-nrd.nhtsa.dot.gov/pd
RNotes/2001/20000SBURNR.pdf, 2001.

16 Williams AF, O'Neill B. Seat belt laws: implications for occupant protection. SÁE Technical Paper Series 790683. Warrendale, PA Society of Automotive Engineers, 1979

17 National Highway Traffic Safety Administration. Observed safety belt use, fall 2000 National Occupant Protection Use Survey. Research note. Washington, DC: US Department of Transportation, 2001.

18 National Highway Traffic Safety Administration. Restraint system usage in the traffic population, 1986 annual report. Report No DOT HS 807 080. Washington, DC: ÚS Department of Transportation, 1987.

19 Williams AF, Wells JK, Lund AK, et al. Observed use of automatic seat belts in 1987 cars. Accid Anal Prev 1989:21:427-33.

20 Block AW. 1998 motor vehicle occupant safety survey; vol 2, seat belt report. Report No DOT HS 809 051. Washington, DC: National Highway Traffic Safety Administration, Office of Research and Traffic Resources, 2000.

21 Nash CE, Friedman D. Petition to amend FMVSS 208, Occupant crash protection, to require effective belt use inducement. Washington, DC, 1998.

22 National Highway Traffic Safety Administration. Federal register. Appendix $A$ to the preamble, response to petition. Washington, DC: Office of the Federal Register, National Archives and Records Administration, 1999:64:214.

23 Automotive Coalition for Traffic Safety. New survey results: ACTS seat belt survey of national drivers. 2001 Seat belt summit: policy options for increasing seat belt use in the United States in 2001 and beyond. Appendix D. Arlington, VA, 2001.

24 US House of Representatives. Making appropriations for the Department of Transportation and related agencies for the fiscal year ending September 30, 2002, and for other purposes. Conference report 107-308, 107th Congress, 1st session. Washington, DC, 2001:97.

\section{LACUNAE}

\section{Motorcycle travel-Cuba}

7 his photo was provided by Susan Scavo Gallagher.

If you have a picture that you think would be of interest to readers please email it to the editor at barry.pless@mcgill.ca (or mail to Barry Pless, Montreal Children's Hospital, C-538, 2300 Tupper, Montreal PQ, Canada H3H IP3)

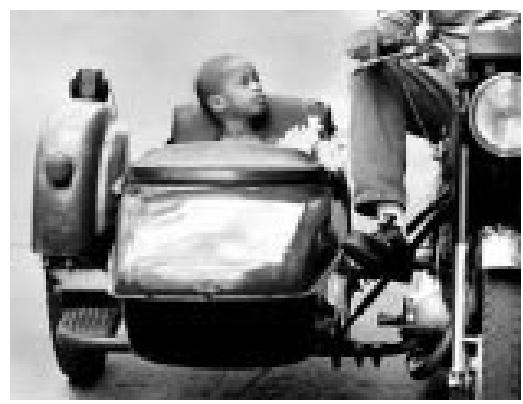

